\title{
PAULUS SANG ENTREPRENEUR: Pembuat Tenda sebagai Jembatan Penginjilan
}

\author{
Junior Natan Silalahi \\ Sekolah Tinggi Teologi Hagiasmos Mission Jakarta \\ drjuniornatansilalahi@stthami.ac.id
}

\begin{abstract}
This article wants to examine Paul's independence as a Gospel Preacher who lives as an entrepreneur. The Apostle Paul as an apostle for Gentiles has special expertise in making tents - used as a support for funding - so that it can help in the continuation of the preaching of the gospel. He does not want to burden the congregation he serves in funding the preaching of the gospel. The expertise he has is used as much as possible to sustain it in service. As an apostle, he is not ashamed to be forthright about what he is doing as a tent maker. And its main purpose is the expertise to make tents used as a bridge for the preaching of the gospel. Thus there are at least two important things obtained from this topic, namely: first, the independence of funds as an evangelist, and second, expertise as a bridge of evangelism. The method of research conducted is qualitative. The study carries out theological approach through biblical studies. In this research, the author will describe Paul as an entrepreneur, and an entrepreneur of evangelistic bridges. The findings in this study showed that it is crucial for gospel preachers emulated Paul who made his expertise a pillar of service so that it did not become a burden on the congregation served. The church must learn to accept the fact that there are pastors who live as entrepreneurs.
\end{abstract}

Keywords: Paul, entrepreneur, evangelism.

Abstrak: Artikel ini ingin mengkaji tentang kemandirian Paulus sebagai Pemberita Injil yang hidup sebagai seorang entrepreneur. Rasul Paulus sebagai rasul bagi orangorang non-Yahudi memiliki keahlian khusus dalam membuat tenda - dijadikan sebagai penopang pendanaan - sehingga dapat membantu dalam kelangsungan pemberitaan Injil. la tidak ingin memberatkan jemaat yang ia layani dalam hal pendanaan pemberitaan Injil. Keahlian yang ia miliki digunakan semaksimal mungkin untuk menopangnya dalam pelayanan. Sebagai rasul, ia tidak malu untuk berterus terang akan apa yang sedang kerjakan yaitu sebagai pembuat tenda. Tujuan utamanya adalah keahlian membuat tenda dipakainya sebagai jembatan untuk pemberitaan Injil. Dengan demikian setidaknya ada dua hal penting yang didapatkan dari topik ini yaitu: pertama, kemandirian dana sebagai penginjil, dan kedua, keahlian sebagai jembatan penginjilan. Metode penelitian yang dilakukan bersifat kualitatif dengan pendekatan teologis. Di dalam artikel ini, penulis memaparkan tentang Paulus sebagai seorang entrepreneur, dan entrepreneur sebagai jembatan penginjilan. Temuan dalam penelitian ini adalah pemberita Injil penting untuk meneladani Paulus yang menjadikan keahliannya sebagai penopang pelayanan, sehingga tidak menjadi beban bagi jemaat yang dilayani. Dari sini, Gereja perlu belajar menerima kenyataan bahwa ada pendeta (pelayan) yang hidup sebagai seorang entrepreneur.

Kata-kata Kunci: Paulus, entrepreneur, penginjilan.

Dewasa ini, pembicaraan mengenai Gereja dan Entrepreneurship

hangat di sekolah-sekolah teologi maupun di gereja-gereja. Pro dan

kontra tak dapat dihindarkan. Erastus Sabdono menulis "tanpa disadari 
terbangun kesan adanya pandangan dualisitis dalam gereja, yaitu usaha untuk membedakan pekerjaan rohani dan pekerjaan sekuler". Menurutnya, terjadi pembedaan antara profesi rohani dan duniawai. Profesi sebagai pendeta, penginjil, pastur, biarawan dan biarawati dianggap sebagai profesi yang rohani, sedangkan dokter, guru, pedagang, insinyur, kontraktor, dan lain-lain dipandang sebagai profesi duniawi (Sabdono, 2016). Sedangkan Palabirin \& Ronda dalam artikelnya memaparkan adanya perbedaan pandangan tentang pendeta bebisnis di kalangan tiga aliran gereja: gereja Injili, gereja Kharismatik, dan gereja Protestan. Beberapa gereja di kalangan gereja Injili, mengijinkan pendeta berbisnis dengan alasan untuk mencukupi kebutuhannya karena penghasilan jemaat yang sedikit. Kalangan gereja Kharismatik tidak membatasi hamba Tuhan penuh waktu yang berbisnis karena mereka melakukan itu semuanya itu untuk menunjang pelayanan serta membantu jemaatnya (Palabirin \& Ronda, 2010). Dengan demikian, maka Alkitab sebagai sumber kebenaran yang mutlak harus dikaji untuk menjawab pro dan kontra tentang topik ini.

Membahas topik tentang entrepreneurship dan gereja, maka akan tertuju pada tokoh Alkitab bernama Paulus. Sebagai seorang rasul yang aktif memberitakan Injil, Paulus juga melakukan pekerjaan sebagai seorang pembuat tenda bersama Akwila dan Priskila di Korintus. la adalah seorang pemberita Injil sekaligus seorang entrepreneur (wirausaha). (bnd. Kis. 18:3).

Prinsip pelayanan Paulus sangat unik karena ia berbeda dengan rasul-rasul yang lain. Salah satu perbedaan ini bisa dilihat ketika ia meneJunior Natan Silalahi 
gaskan bahwa sebagai seorang penginjil ia tidak mau membebani jemaat yang dilayani. la juga tegas untuk tidak menerima imbalan apapun atas pemberitaan Injil yang dilakukannya meskipun sebenarnya ia berhak untuk itu.

Paulus menjelaskan tentang alasan di balik sikapnya yaitu bahwa daripada ia menerima tunjangan tetapi pemberitaan Injil justru menjadi terhalang, maka ia lebih memilih bekerja untuk penghidupannya. Bagi Paulus tidak ada yang istimewa dari tugas pemberitaan Injil yang ia lakukan, karena ini merupakan keharusan ilahi bagi dirinya. la hanya melakukan apa yang seharusnya ia lakukan. Paulus melihat dirinya sebagai seorang budak yang dipercayakan untuk memberitakan Injil. Ketika seorang budak menyelesaikan pekerjaannya, ia tidak boleh mengharapkan upah dari apa yang ia kerjakan.

Prinsip Paulus ini sekaligus menjadi pelajaran yang konkrit dalam pemberitaan Inji, yaitu bahwa pemberitaan Injil yang tanpa pamrih akan menegaskan tentang hakikat Injil yang adalah anugerah Allah. Dengan menghidupi dirinya sendiri, Paulus terbebas dari beban mental sebagai seorang penginjil. la menjadi sangat leluasa dalam pemberitaan Injil. (Band Kis. 18:3).

Oleh sebab itu, penting adanya suatu kajian tentang prinsip penginjilan rasul Paulus secara khusus kegiatannya sebagai seorang entrepreneur (wirausahawan) yang dapat dijadikan sebagai suatu teladan bagi para penginjil masa kini dan suatu perbandingan dalam pelaksanaan prinsip hamba Tuhan sebagai seorang entrepreuner. 


\section{METODE}

Metode penelitian yang dilakukan dalam artikel ini bersifat kualitatif. Menurut Sugiyono, penelitian kualitatif adalah metode penelitin yang berlandaskan pada filsafat postpositivisme, digunakan untuk meneliti pada kondisi obyek yang alamiah, (sebagai lawannya adalah eksperimen) di mana peneliti sebagai instrumen kunci, teknik pengumpulan data dilakukan secara triangulasi (gabungan), analisa data bersifat induktif/kualitatif, dan hasil penelitian kualitatif lebih menekankan makna dari pada generalisasi (Sugiyono, 2013, p. 24).

Adapun kajian yang digunakan dalam riset ini adalah studi teologis. Studi adalah penelitian ilmiah; kajian; telaahan (KBBI, 2016). Kata teologi berasal dari bahasa Yunani, theos - Allah dan logos - Firman. Studi mengenai Allah. Semua mata pelajaran yang membentuk pelajaran untuk studi teologi (Manton, 2001). Sedangkan kata teologis artinya berhubungan dengan teologi; berdasar pada teologi (KBBI, 2016, p. 1177). Artikel ini merupakan studi teologis Kisah Para Rasul 18:3 tentang Paulus sebagai seorang entrepreuner.

Studi ini dilakukan dalam bentuk kajian terhadap bahasa asli Alkitab Perjanjian Baru, yaitu bahasa Yunani, khususnya bagian yang berkaitan dengan Paulus sebagai seorang entrepreuner yaitu Kis.18:3. Dalam ayat ini, yang menjadi sorotan utama adalah frasa tukang tenda. Langkah pertama adalah mengkaji makna frasa ini. Langkah kedua, mengkaji keberhasilan Paulus dalam pemberitaan Injil di Korintus lewat strategi menjadi seorang pembuat tenda (kemah). Langkah ketiga, mene- 
rapkan strategi penginjilan Paulus sebagai seorang entrepreuner bagi penginjil/pelayan Tuhan pada masa kini.

\section{HASIL}

\section{Mengenal Rasul Paulus}

Kisah hidup rasul Paulus hanya bisa didapat dari dua sumber yaitu dari kitab Kisah Para Rasul dan surat-surat yang ditulisnya. (Silalahi, 2019, p. 40). la adalah orang Yahudi asli (Rom 11,1; 2 Kor 11,22; Flp 3,5) dari keturunan suku Benyamin yang berasal dari Tarsus (Kis 9:11, 30; 11:25; 21:39; 22:3) dan berkewarganegaraan Roma. (Kis. 22, 23, 26, 28).

Paulus mengaku "dididik dengan teliti di bawah pimpinan Gamaliel dalam hukum nenek moyang kita, sehingga aku menjadi seorang yang giat bekerja bagi Allah sama seperti kamu semua pada waktu ini" (Kis 22,3). Gamaliel adalah seorang rabi terkenal dari aliran Hillel yang merupakan aliran Farisi yang moderat (aliran utama yang lain adalah aliran Shammai yang lebih keras). Di tempat lain Paulus mengatakan bahwa ia "telah hidup sebagai seorang Farisi menurut aliran yang paling keras dalam agama kita" (Kis 26,5). Sementara dalam suratnya Paulus menyatakan, "tentang pendirian terhadap hukum Taurat aku orang Farisi, tentang kegiatan aku penganiaya jemaat, tentang kebenaran dalam menaati hukum Taurat aku tidak bercacat" (Flp 3,5-6). Bagaimana pun, Paulus ditampilkan sebagai seorang yang mempunyai pendirian keras dalam hukum Taurat; ia adalah seorang yang intoleran. 
Sebagai seorang Farisi yang amat fanatik, Paulus menentang jemaat Kristen atau para pengikut Kristus karena menganggap mereka adalah orang-orang Yahudi yang menyeleweng dari ajaran agama Yahudi dengan menganggap Yesus sebagai Mesias. Keyakinan bahwa Yesus adalah Mesias adalah sesuatu yang tidak masuk akal, suatu kebodohan dan merupakan batu sandungan bagi orang Yahudi. la turut aktif dalam kegiatan penghambatan dan penganiayaan kegiatan penginjilan.

Namun sebuah pengalaman unik dialaminya dalam perjalanannya ke Damsyik (Kis 9,1-9; 22,1-16; 26,12-23). Di sini, Paulus yang kegiatannya menganiaya jemaat (Flp 3,6) bertemu dengan Yesus yang dianiaya itu (Kis 9,5; 22,8; 26,15). Pengalaman ini adalah amat luar biasa sehingga membawanya "bertobat".

Terjadi perubahan yang begitu radikal dan tiba-tiba dalam kehidupannya. Paulus memang mengakui bahwa peristiwa 'pertobatannya' adalah suatu peristiwa rahmat $(\mathrm{Rm} 1,5$; 1 Kor 15,9-10; Gal 1,15). la sekarang tidak lagi menganiaya jemaat-jemaat pengikut Kristus, melainkan menjadi seorang pemberita Injil yang luar biasa. Demikianlah, orang yang tadinya berusaha menangkap para pengikut Kristus, akhirnya malah "ditangkap oleh Kristus Yesus" (Flp 3,12) (Drane, 2016, p. 132).

\section{Strategi Penginjilan Paulus}

Pandangan misi Paulus sangat luas, bersifat mendunia, setidaktidaknya dunia yang dikenal olehnya. Paulus melihat bahwa misi bersifat universal, dalam pengertian bahwa seluruh dunia yang didiami harus dijangkau dengan Injil. Visi misioner ini didapat mulai menggema di hati 
Paulus setelah sidang di Yerusalem (tahun $48 \mathrm{M}$ ), karena sebelumnya jangkauan misi kepada bangsa-bangsa Yahudi terbatas sampai ke Siria dan Kilkia (bnd. Gal. 1:21; jemaat di Roma, berasal dari awal tahun 40-an dari abad pertama Masehi, dimulai sebagai sebuah jemaat Kristen Yahudi (Bosch, 2009). la adalah perintis pekabaran Injil, utusan Kristus kepada bangsa-bangsa bukan Yahudi. la pindah ke tempat-tempat lain karena ia mempunyai ambisi memberitakan injil bukan di tempat dimana Kristus dikenal (Rm. 15:20). Menurut David J. Bosch,

kemungkinan ada dua alasannya: (a) mengingat singkatnya waktu dan mendesaknya tugasnya, sungguh suatu penatalayanan yang buruk bila ia pergi ke tempat-tempat dimana orang-orang lain telah memberitakan Injil; (b) ia tidak bermaksud mengatakan bahwa karya misi sudah selesai di wilayah-wilayah di mana ia telah bekerja, tetapi semata-mata bahwa di sana telah ada jemaat-jemaat yang mampu berdiri sendiri, yang mungkin menjangkau ke wilayahwilayah pedalamannya sendiri; karena itu ia harus pindah ke "wilayah-wilayah di luarnya". (Bosch, 2009, p. 205).

Usaha misi Paulus dilakukan dengan cara berkhotbah dari satu tempat ke tempat lain, sebab itu ia disebut sebagai pengkhotbah keliling. Namun di beberapa tempat ia tinggal untuk waktu yang lebih lama (sekitar satu setengah tahun di Korintus, dua sampai tiga tahun di Efesus). Ollrog (1979: 125-129, 158) mengatakan bahwa Paulus terlibat dalam "Zentrumsmission", artinya, misi di pusat-pusat strategis tertentu. Paulus sering menyebut bahwa misinya ditujukan ke berbagai negara dan wilayah geografis (Gal. 1:17, 21; Rm. 15:19, 23, 26, 28; 2 Kor. 10:16). Tentu saja pemilihan tempat-tempat ini merupakan suatu perencanaan yang matang. Paulus memusatkan misinya pada distrik atau ibu kota provinsi, yang masing-masing mewakili seluruh wilayahnya: 
Filipi untuk Makedonia (Flp. 4:15), Tesalonika untuk Makedonia dan Akhaya (1 Tes. 1:7), Korintus untuk Akhaya (1 Kor. 16:15; 2 Kor. 1:1) dan Efesus untuk Asia (Rm. 16:5; 1 Kor. 16:19; 2 Kor. 1:8). "Metropolismetropolis" ini adalah pusat-pusat utama sejauh menyangkut komunikasi, budaya, perdagangan, politik dan agama. Paulus memilih kotakota yang mempunyai ciri mewakili. Di kota-kota tersebut ia meletakkan dasar-dasar untuk komunitas Kristen, dengan harapan bahwa melalui pusat-pusat strategis ini, Injil akan dibawa ke pedesaan dan kota-kota sekitarnya. Strategi ini ternyata membuahkan hasil yang besar. Dalam suratnya yang pertama sekali, yang ditulis kepada orang-orang percaya di Tesalonika (1 Tes. 1:8) di mana kurang dari setahun setelah ia tiba di sana, ia mengatakan bahwa Injil bergema bukan hanya di Makedonia dan Akhaya saja tetapi di semua tempat (Bosch, 2009).

Paulus berkeliling ke berbagai tempat strategis memberitakan Injil termasuk mendirikan jemaat. Dalam perjalanan pemberitaan Injil ini, Paulus berkarya sebagai seorang tukang tenda dan sebagai ahli kitab.

\section{Paulus Sang Entrepreneur}

Dalam Kamus Besar Bahasa Indonesia, kata wirausaha (Inggris: entrepreneur) atau wiraswasta, adalah orang yang pandai atau berbakat mengenali produk baru, menentukan cara produksi baru, menyusun manajemen operasi untuk pengadaan produk baru, memasarkannya, serta mengatur permodalan operasinya (KBBI, 2016). Wirausahawan atau entrepreneur adalah orang yang melakukan kegiatan kreativitas untuk menciptakan perubahan dengan memanfaat- 
peluang dan sumber-sumber yang ada untuk menghasilkan nilai tambah bagi diri sendiri dan orang lain.

Paulus adalah seorang entrepreneur. Penjelasan mengenai hal ini terdapat dalam Kisah Para Rasul 18:3, di mana dikatakan bahwa ia adalah seorang "tukang kemah".

TB: Dan karena mereka melakukan pekerjaan yang sama, ia tinggal bersama-sama dengan mereka. Mereka bekerja bersamasama, karena mereka sama-sama tukang kemah. (LAl, 2013:192)

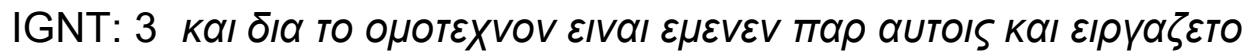

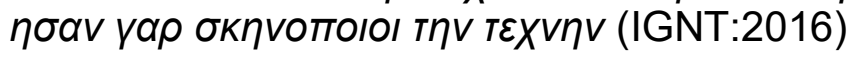

(Baca: Kai dia to homotekhnon einai emenen par autois kai eirgazeto esan gar skenopoioi ten tekhnen)

NKJV: 3 So, because he was of the same trade, he stayed with them and worked; for by occupation they were tentmakers (SABDA NKJV, 2016).

\section{Konteks}

Kis. 18:1 mencatat bahwa Paulus meninggalkan Atena untuk pergi ke Korintus, di mana dia menantikan kedatangan Silas dan Timotius dari Makedonia. Korintus adalah ibu kota propinsi Akhaya, kota kosmopolitan sekaligus pusat perdagangan yang ramai. Di kota ini, Paulus bertemu dengan Akwila dan Priskila, isterinya, dan singgah ke rumah mereka (Pfeiffer, 2014). Pasangan suami-istri ini meninggalkan Roma karena Kaisar Klaudius (AD 41-54) mengusir semua orang Yahudi dari sana (bdk. Kis 18:2). Paulus bertemu mereka dalam perjalanan misinya yang kedua sekitar tahun 50, setelah menghadiri Konsili Yerusalem yang mungkin diadakan tahun 49 (Tantiono, 2009). Tampaknya hubungan mereka cukup akrab. Paulus biasa menginap di rumah mereka. 


\section{"Mereka Melakukan Pekerjaan yang Sama"}

Mereka bekerja bersama-sama, karena mereka sama-sama tukang tenda. Akwila dan Priskila adalah suami isteri, orang Yahudi yang bekerja sebagai tukang kulit (Kis 18:3). Paulus, Akwila dan Priskila

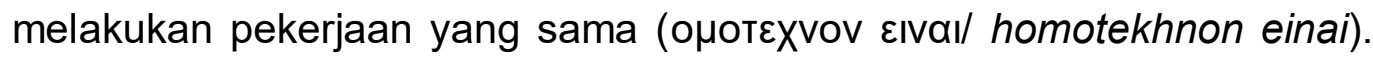
Profesi yang sama menambah keeratan persahabatan antara Paulus, Akwila dan Priskila. Frasa "pekerjaan yang sama" ini juga menegaskan bahwa sang rasul benar-benar menggeluti dunia kerja. la masuk dalam dunia entrepreneurship. Rasul Paulus adalah seorang entrepreneur.

\section{"Mereka Sama-Sama Tukang Kemah"}

Ayat ini dengan terang menyetakan bahwa "mereka bekerja bersama-sama, karena mereka sama-sama tukang kemah". Kata ganti “mereka" menunjuk pada Paulus di satu sisi dan Akwila dan Priskila di pihak lain. Kata ganti "mereka" merupakan kata ganti orang yaitu: Paulus, Akwila dan Priskila. Kemudian kalimat berikutnya adalah "karena mereka

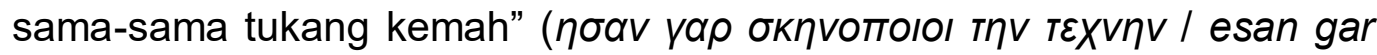
skenopoioi ten tekhnen).

Mereka berprofesi sebagai tukang kemah. Frasa "tukang kemah" atau "pembuat tenda" dalam bahasa Yunani: skenopoioil Inggris: tent makers. (Stefan, 2017). Akhiran oi pada kata Yunani skenopoioi berbentuk plural (jamak) hendak menjelaskan bahwa baik Paulus, Akwila dan Priskila melakukan pekerjaan yang sama sebagai pembuat tenda. Kata Yunani skenopoioi berasal dari kata dasar skete yang artinya adalah seorang pembuat tenda. 


\section{Tukang Tenda sebagai Jembatan Penginjilan}

Di Korintus, Paulus melakukan pekerjaan lain di samping memberitakan Injil; dia seorang tukang kemah, serta mencari nafkah dengan cara ini sepanjang perjalanannya atau ketika tinggal di suatu tempat (Kis 20:34; 1Tes 2:9; 2Tes 3:8). Dari teladan Paulus jelaslah bahwa hambahamba Tuhan yang harus bekerja untuk menghidupi diri dan keluarga tidak melakukan hal yang salah. Alkitab dan para rasul telah memberi contoh lebih dahulu tentang hal merangkap pekerjaan (Stamps, 1999). John R. Tan menegaskan bahwa Allah mempertemukan Paulus dengan Akwila dan Prikila yang ternyata memiliki profesi yang sama sebagai pembuat tenda dan menjadi teman akrab dalam pelayanan penginjilan (Tan, 2007).

Sedangkan dalam 1 Kor. 4:12, ia berkata tentang "melakukan pekerjaan tangan yang berat". la bekerja begitu supaya jangan menjadi beban siapapun juga (1 Tes. 2:9). Hal itu diuraikan dengan lebih jelas dalam "pembelaannya" terhadap lawan-lawannya di Korintus (1 Kor 9:3). Dalam 1 Kor 9:6 ia berkata bahwa sebetulnya ia (dan Barnabas) sama seperti rasul-rasul lainnya "mempunyai hak untuk dibebaskan dari pekerjaan tangan". Namun, pekerjaannya sebagai tukang tenda ia manfaatkan untuk pemberitaan Injil. Sesuai dengan adat kebiasaan zaman itu, khususnya dalam lingkup Yunani, tempat kerja terbuka dan dipakai untuk diskusi atau setidak-tidaknya untuk berbicara dan bertukar pikiran (Jacob, 1995).

Menurut F.F. Bruce profesi yang lebih tepat untuk Paulus adalah 
seorang 'tukang kulit'. Meskipun F.F. Bruce tidak menjelaskan alasannya mengapa ia berpendapat demikian. Namun menurutnya, adalah suatu kewajaran apabila seorang rabi melakukan pekerjaan tangan supaya ia jangan mengambil keuntungan dari pengajaran agama yang ia berikan (Bruce, 2013).

Sedangkan menurut Wycliffe, mungkin yang dimaksud dalam Kisah Para Rasul 18:3 mengenai pekerjaannya sebagai tukang kemah adalah menjahit kain yang berat dari bulu kambing yang kemudian dijadikan kemah: atau "ahli mengolah kulit". Hal ini diperkuat dengan adanya suatu kebiasaan di kalangan para rabi Yahudi untuk tidak menerima bayaran atas kegiatan mengajar mereka, karena itu Paulus dididik sebagai rabi, telah belajar cara untuk membuat kemah. Rasul Paulus tidak langsung memberitakan Injil di Korintus tetapi bergabung dahulu dengan Akwila dan Priskila mempraktikkan pekerjaan tersebut sepanjang minggu itu (Pfeiffer, 2014).

Ketika memberitakan Injil di rumah ibadat orang Yahudi (Sinagoge), Paulus mengalami penolakan dari orang-orang Yahudi. Mereka memusuhi dan menghujat dirinya. Adapun posisi di sebelah rumah ibadat Yahudi terdapat rumah yang dimiliki oleh seorang yang bernama Titius Yustus, orang bukan Yahudi yang takut akan Allah yang mengunjungi rumah ibadat itu. Dia membuka rumahnya kepada Paulus untuk memberitakan Injil bila sang rasul pulang dari rumah ibadat. Penolakan tersebut tidak membuat Paulus putus asa untuk memberitakan Injil, ia tetap berusaha untuk memberitakan berita keselamatan itu. Tidak dapat dianggap remeh, Krispus yang adalah ke- 
pala rumah ibadat justru percaya dan memberi diri dibaptis oleh Paulus. Bertobatnya Krispus, kepala rumah ibadat bersama dengan seluruh keluarganya, dan banyak lagi dari orang-orang Korintus yang mendengarkan pemberitaan Injil oleh Paulus pada akhirnya menjadi percaya dan memberi diri mereka dibaptis.

Cerita tentang pembaptisan Krispus dapat ditemukan dalam 1 Korintus 1:14. Di sini Paulus mengucap syukur kepada Allah bahwa ia membaptis Krispus dan Gayus. Allah menuntunnya untuk membaptis jumlah yang sedikit di Korintus. Dalam hal ini Paulus tidak sedang menganggap rendap makna dari baptisan yang ia lakukan, namun ia tidak mau menyombongkan dirinya kepada siapapun akan hal itu. Sebab, ia menyadari bahwa tugas utamanya bukanlah untuk membaptis, melainkan memberitakan Injil kabar keselamatan.

Melalui kegiatan sebagai pembuat tenda, Paulus dapat lebih leluasa untuk memberitakan Injil kepada orang-orang Yahudi. Hal ini membuktikan bahwa betapa pentingnya "jembatan penginjilan" bagi seorang pemberita Injil. Paulus yang adalah seorang entrepreneur bersama Akwila dan Priskila sangat dekat dengan masyarakat sehingga dapat berkomunikasi dengan mudah. Bagi Paulus, kegiatannya sebagai pembuat tenda bukanlah merupakan tujuan utama melainkan sebagai penunjang untuk kegiatan pewartaan Injil. Paulus bukan bertujuan untuk mencari harta dan kekayaan lewat kegiatannya itu. la hanya memakainya sebagai media penginjilan kepada orang banyak. Kota Korintus yang merupakan kota perdagangan sangat cocok dan strategis bagi Paulus untuk melakukan kegiatannya sebagai tukang tenda (ke- 
mah). Di Kota Korintus tentu akan banyak orang yang memerlukan hasil buatan Paulus, Akwila dan Priskila. Lewat kegiatannya ini, Paulus berhasil menjauhkan pemisah antara si penginjil dan objek penginjilan.

\section{PEMBAHASAN}

\section{Entrepreneurship sebagai Jembatan Penginjilan}

Dari hasil pemaparan di atas, sangat jelas bahwa suatu profesi dapat dijadikan sebagai jembatan penginjilan. Pekabaran Injil dapat berlangsung dengan baik karena pewarta melayankannya dengan lebih elegan dan tidak frontal. Profesi yang ditekuni akan membuat tugas pewartaan Injil lebih masuk ke dalam masyarakat, sehingga menghilangkan antipati, skeptis, dan ketidaknyamanan. "Jembatan Penginjilan" dibutuhkan sebagai media untuk menembus batas-batas yang ada antara penginjil dan obyek penginjilan. Dalam hal ini Erastus menegaskan bahwa entrepreneurship itu sendiri adalah pelayanan untuk mendukung proses keselamatan.

\section{Entrepreneurship dalam Perwujudan Amanat Agung}

Entrepreunership adalah bagian dari proyek Tuhan untuk mewujudkan Amanat Agung-Nya agar rencana-Nya digenapi (Sabdono, 2016). Tak berlebihan jika dikatakan bahwa William Carey (1761-1834) "Bapa Pekabaran Injil Modern " ini dapat digolongkan sebagai seorang entrepreneur. la memakai metode penginjilan dengan berprofesi sebagai seorang tukang sepatu. Hasilnya Carey dapat meletakkan dasar pekabaran Injil di India. (End, 2003:318) 


\section{Entrepreneurship Membangun Ekonomi Jemaat}

Praktik kewirausahaan terbukti berhasil membangun ekonomi jemaat dan menopang perkembangan pelayanan. Setidaknya, hal inilah yang dilakukan Ludwig Ingwer Nomensen (1834-1918) dalam perintisan gereja HKBP. Kegiatan kewirausahaan menjadi penunjang keberhasilan Nomensen dalam merintis gereja HKBP. Selain pemberitaan Injil, Nommensen juga memperhatikan persoalan-persoalan ekonomi; ada mesin-mesin penggiling padi, membangun jalan-jalan dan mendirikan koperasi peminjaman bung rendah. Injil mengubah seluruh kehidupan rakyat; tidak ada pemisahan antara yang "rohani" dengan yang "jasmani" . (End, 2003).

Pada era revolusi 4.0 ini, para pekabar Injil (pendeta, evangelis, majelis) tentu dapat saja memakai peluang yang luas ini untuk dipakai sebagai media penginjilan. Sesungguhnya setiap profesi dapat dijadikan sebagai jembatan penginjilan untuk tugas yang mulia. Bekerja sebagai seorang entrepreneur tidak mengurangi kualitas sebagai seorang pewarta Injil, asalkan dengan motivasi yang teguh dan sadar akan tugasnya yang utama yaitu melaksanakan Amanat Agung.

\section{KESIMPULAN}

Dari hasil pembahasan di atas, penulis menarik beberapa kesimpulan yang penting di antaranya: pendeta sebagai entrepreneur bukanlah dosa, pendeta memiliki keahlian, dan praktik entrepreneurship menopang pelayanan. 


\section{Pendeta sebagai Entrepreneur Bukanlah Dosa}

Pendeta yang memiliki panggilan dalam bidang entrepreneurship merupakan hal yang baik dan wajar karena Tuhan mempercayakan keahlian tersendiri di dalam diri seseorang yang kelak sangat diperlukan dalam pelayanan. Praktik pendeta sekaligus sebagai seorang entrepreneur bukanlah dosa dan melanggar kebenaran firman Allah (Alkitab). Hal ini dibuktikan dengan apa yang dilakukan oleh rasul Paulus sebagai pembuat tendah (kemah). Oleh sebab itu, gereja tidak perlu anti pati terhadap pendeta yang berprofesi sebagai seorang entrepreneur.

\section{Pendeta Memiliki Keahlian}

Para pendeta atau bahkan penginjil pada masa kini dapat menggunakan keahlian yang ia miliki untuk menunjang kegiatan pelayanan. Keahlian yang dimiliki oleh setiap orang tentu sangat bermanfaat dalam pelayanan. Keahlian dalam diri seseorang dapat diasah dan dibentuk lewat pelatihan baik di gereja, seminari, maupun tempat pelatihan umum. Gereja dan seminari tidak perlu antipati untuk melatih para calon penginjil dengan keterampilan umum seperti: menjahit, salon, service, pertanian, perkebunan dan sebagainya. Dengan demikian, maka gereja, lembaga misi, seminari sebagai pengutus para penginjil tidak perlu kuatir akan pemenuhan kebutuhan pribadi penginjil.

\section{Praktik Entrepreneurship Menopang Pelayanan}

Sebagai hamba Tuhan tugas pewartaan Injil adalah suatu kewajiban, dan upahnya ialah memberitakan Injil tanpa upah. Dengan 
seorang entrepreneur di ladang misi sehingga tidak menjadi beban bagi siapapun. Hal ini tentunya bukan berarti mengabaikan kewajiban lembaga yang mengutus, namun setidaknya akan meringankan beban. Pelayan Tuhan masa kini harus meneladani sikap rasul Paulus yang tidak memusingkan diri dengan kebutuhan dana penginjilan sebab ia dapat memenuhinya.

Akan tetapi, sebagai seorang entrepreneur jangan sampai terjebak pada mencari keuntungan pribadi sehingga menghiraukan tugas sebagai pemberita Injil. Demikian sebaliknya, mengabarkan Injil jangan dijadikan sebagai ajang untuk mencari keuntungan pribadi, para hamba Tuhan jangan sampai terjebak di dalamnya. Sebab Tuhan mengingikan para pelayannya memiliki motivasi yang murni dalam menunaikan tugas panggilannya. Tidak tercemar dengan dunia yang penuh dengan ukuran materialisme. Dunia mengukur segala sesuatu dengan uang - tidak ada pekerjaan tanpa uang - bahkan penginjilanpun dijadikan sebagai lahan untuk mencari uang. Oleh sebab itu hamba Tuhan masa kini harus memiliki integritas yang tinggi sebagai pelayan Tuhan, bukan motivasi untuk mencari keuntungan. Tujuan dari pelayanan adalah untuk kemuliaan nama Tuhan, menyenangkan hati Tuhan, dan menjangkau yang terhilang.

\section{DAFTAR PUSTAKA}

Bosch, D. J. . (2009). Transformasi Misi Kristen. Jakarta: BPK Gunung Mulia.

Bruce, F. (2013). Tafsiran Alkitab Masa Kini 3. Jakarta: YKBK/OMF. 
Drane, J. (2016). Memahami Perjanjian Baru. Jakarta: BPK Gunung Mulia.

End, T. Van den. (2003). Harta dalam Bejana: sejarah gereja ringkas. Jakarta: BPK Gunung Mulia.

Jacob, T. (1995). Paulus: Hidup, Karya dan Teologinya. Jakarta: BPK Gunung Mulia.

KBBI. (2016). KBBI - Kamus Besar Bahasa Indonesia. In Kbbi.Kemdikbud.Go.ld (3rd ed.). Jakarta: Balai Pustaka.

Manton, M. E. (2001). Kamus Istilalh Teologi. Malang: Gandum Mas.

Palabirin, B., \& Ronda, D. (2010). Pandangan Alkitab Tentang Praktik Bisnis di Kalangan Hamba Tuhan Penuh Waktu. Jurnal Jaffray, 8(2), 35. https://doi.org/10.25278/jj71.v8i2.45

Pfeiffer, C. F. (2014). Tafsiran Alkitab Perjanjian Baru. Malang: Gandum Mas.

SABDA NKJV. (2016). Jakarta: SABDA.

Sabdono, E. (2016). Biblical Entrepreneurship. Jakarta: Rehobot Literature.

Silalahi, J. N. (2019). Paulus dan Filsuf di Atena Strategi Penginjilan Paulus di Atena dalam Kisah Para Rasul 17:16-34. Jakarta: Yayasan Covindo.

Stamps, D. C. (1999). Alkitab Penuntun Hidup Berkelimpahan. Malang: Gandum Mas.

Sugiyono. (2013). Cara Mudah Menyusun: Skripsi, Tesis dan Disertasi. Bandung: Alfabeta.

Tan, J. R. (2007). Paulus Rasul Kristus ke-13. Jakarta: Seminari Bethel Publishing.

Tantiono, P. T. (2009). Pengaruh Rasul Paulus dalam Sejarah Kekristenan: Sebelum - Sesudah Pertobatan - Tradisi. Logos, 7(1). 